\title{
EFFICIENCY OF THE NEW OINTMENT "ALLERGOLIK" ON THE EXPERIMENTAL MODEL OF TURPENTINE-INDUSED DERMATITIS IN RATS
}

For topical medication of the inflammatory skin diseases are promising herbal medicinal products. The antiinflammatory effect of the ointment "Allergolik", which contained the dry extract of licorice rhizome and the reference drug (2\% ointment "Fladeks" was studied on the model of turpentine-induced dermatitis in rats. Effectiveness of the ointment "Allergolik" was evaluated by the total number of leukocytes and leukocyte composition in the peripheral blood, the skinfold thickness and the state of the skin. Based on our studies it was shown that the ointment "Allergolik" had pronounced anti-inflammatory effect and was more active drug compared with reference drug "Fladeks".

Key words: licorice root extract; anti-inflammatory activity; turpentine-induced dermatitis

\section{INTRODUCTION}

The unifying symptom of the most common skin diseases, such as allergic dermatitis, is an inflammation of the skin. Eradication of inflammation, which means inhibition of the synthesis of pro-inflammatory factors (cytokines, prostaglandins, and histamine), elimination of endothelial dysfunction, reduction of the immune-cells hyperactivation is one of the key objectives of the treatment of inflammatory skin diseases, to ensure the stability of the therapeutic effect [13].

Topical medication of the inflammatory skin diseases includes a wide arsenal of various means: topical corticosteroids, selective inhibitors of calcineurin, topical antihistamines, emollients, keratoplastic and keratolytic agents, remedies for epithelization, traditional anti-inflammatory drugs [9]. Topical herbal medicinal products differs positively from previously medicinal agents because they have complex pharmaceutical effect, can be used for longterm treatment without significant side effects, have relatively low cost and easier manufacture.

Licorice (Glycyrrhiza glabra/uralensis) [6] is a known crude drug. The rhizome of licorice contains glycyrrhizin, a triterpenic saponin, flavonoids, sterols, asparagine, glycyrrhetinic acid, coumarins (umbelliferone and herniaryn), ascorbic acid and other compounds [2]. A wide range of biological activity of drugs on the basis of licorice rhizome is reflected in the constant growth of patents on its application [3].

The aim of this study was investigated the anti-inflammatory activity of the ointment "Allergolik", which

(c) Maloshtan L. M., Zeghdani Esam A. Zurgani,

Shakina L. O., 2016 contains the dry extract of licorice rhizome, on the experimental model of turpentine-indused dermatitis in rats.

\section{MATERIALS AND METHODS}

As a reference drug was used the ointment codenamed "Allergolik" was developed at the Department of Drug Technology under the guidance of Professor Yarnykh T. G. As a reference drug was used ointment "Fladeks" - $2 \%$. It is an ointment for external use (LLC "Pharmaceutical company "Zdorovie"”, Kharkov, Ukraine), which has anti-inflammatory, anti-pruritic, analgesic topical effects, exhibits anti-allergic and desensitizing properties and stimulates repair processes in skin.

In the experiment was used 24 white nonlinear rats 260-300 g weight. Experimental animals were divided into 4 groups ( 6 animals in each group): I group is intact control, II group is positive control - untreated animals with turpentine dermatitis, III group is experimental animals with turpentine dermatitis wich were treated with the ointment "Allergolik", IV group is reference group animals with turpentine dermatitis were treated with reference drug - ointment "Fladeks".

For modeling pathology, turpentine was applied on the depilated area of the animals' skin daily for 10 days [10]. Skin treatment was began immediately after the pathology modeling for the next five days. Effectiveness of the ointment "Allergolik" was evaluated by the total number of white blood cells in the peripheral blood (total leukocytes) and leukocyte composition [4], the skinfold thickness, which was measured using caliper in $\mathrm{mm}$, and the state of the skin. The degree of inflammatory manifestations in the skin was evaluated in points: 0 points is lack of the response; 1 point is poorly marked erythema with scalling; 


\section{THE INTENSITY OF THE INFLAMMATORY SKIN LESIONS ON THE EXPERIMENTAL MODEL OF TURPENTINE-INDUSED DERMATITIS IN RATS, POINTS $\left(\overline{\mathrm{X}} \pm S_{\mathrm{x}}, \mathrm{n}=6\right)$}

\begin{tabular}{|l|c|c|c|}
\hline \multicolumn{1}{|c|}{ Observation term } & $\begin{array}{c}\text { Dermatitis without } \\
\text { treatment (group II) }\end{array}$ & $\begin{array}{c}\text { Dermatitis + ointment } \\
\text { "Allergolik" (group III) }\end{array}$ & $\begin{array}{c}\text { Dermatitis + ointment } \\
\text { "Fladeks" (group IV) }\end{array}$ \\
\hline $\begin{array}{l}\text { 10-th day of the experiment } \\
\text { (modeling of dermatitis was finished) }\end{array}$ & $2.83 \pm 0.17$ & $2.67 \pm 0.21$ & $2.67 \pm 0.21$ \\
\hline $\begin{array}{l}\text { 15-th day of the experiment } \\
\text { (5-th day of the skin treatment) }\end{array}$ & $2.00 \pm 0.01^{*}$ & $0.67 \pm 0.21^{*} /^{* *} /^{* * *}$ & $1.33 \pm 0.21^{*} /{ }^{* *}$ \\
\hline
\end{tabular}

Note: $\mathrm{n}$ - the number of animals in each group; ${ }^{*}$ - differences between 10 -th day and 15 -th day of the experiment, $\mathrm{p}<0.05$;

** - diffrences from group II, $\mathrm{p}<0.05$; ${ }^{* * *}$ - differences between groups III and IV, $\mathrm{p}<0.05$.

2 points is moderate erythema with scalling, petechial hemorrhages; 3 points is severe erythema, skin ulcers.

All parameters were determined: before the experiment (baseline), on the 10-th day of turpentine applying (the last day of disease modeling); on the last day of the local treatment (5-th day of the skin treatment or 15-th day of the experiment).

This study was carried out in strict accordance with general ethical principles of animal experiments, approved by the First National Congress on Bioethics (Kiev, 2001) and agreed with the statements of the "European Convention for the Protection of Vertebrate Animals Used for Experimental and Other Scientific Purposes" (Strasbourg, 1985) $[8,12]$. Laboratory animals were kept under vivarium conditions and used in the research according to the recommendations [15].

Experimental data were statistically processed by means of Statistica 6.0 software (Stat Soft Inc.). Statistical data processing was carried out using the software package Statistica for Windows 6.0. The results were considered valid when $\mathrm{p}<0.05$ [7].

\section{RESULTS AND DISCUSSION}

The results concerning to anti-inflammatory activity of ointment with dry extract of licorice root on the experimental model of turpentine-induced dermatitis are shown in Tab. 1-3.

Clinical manifestations of turpentine dermatitis were reached a peak of intensity on the 10-th day of the experiment. Inflammation of the skin was characterized by tissue edema, severe erythema, petechial hemorrhages and hemorrhagic crusts with skin ulcers, which was evaluated in 2.67-2.83 point in the groups II, III, IV (Tab. 1). Skinfold thickness was increased in 2.2-2.5 times $(\mathrm{p}<0.05)$ compared with the baseline data (Tab. 2).

Local manifestations of turpentine dermatitis were accompanied by increased reactivity, which was appeared in significant increase of total leukocytes number (in 3 times), banded (in 2.1 times) and segmented (in 1.3-1.8 times) neutrophils, eosinophils, basophils and monocytes against decrease the number of lymphocytes (in 1.1-1.3 times) in groups II, III, IV relatively to intact control (group I) and baseline data (Tab. 3). There was a deterioration in general health of the animals: violation of motor activity and loss of appetite.

After the treatment with the ointment, which contained the dry extract of licorice rhizome (on the 5th day of the skin treatment or 15-th day of the experiment). It was shown a significant decrease of skinfold thickness (in 1, 4 times) and reduced of inflammatory manifestations in the skin (in 3 times) compared with untreated animals with turpentine dermatitis (Tab. 1, 2). In the group of animals were treated with reference drug "Fladeks", reliable reduction of the skinfold thickness in 1.3 times and decrease of inflammatory manifestations in the skin in 1.5 times only were observed compared with positive control group (Tab. 1, 2). Such wise ointment, which contained the dry extract of licorice rhizome, suppressed inflammatory processes in the skin much more significantly compared with reference drug "Fladeks".

On the background of the treatment with the ointment, which containes the dry extract of licorice rhizome

Table 2

\section{THE SKINFOLD THICKNESS ON THE EXPERIMENTAL MODEL OF TURPENTINE-INDUSED DERMATITIS IN RATS, MM $\left(\overline{\mathrm{X}} \pm S_{\mathrm{x}}, \mathrm{n}=6\right)$}

\begin{tabular}{|l|c|c|c|c|}
\hline \multicolumn{1}{|c|}{ Observation term } & $\begin{array}{c}\text { Intact animals } \\
\text { (group I) }\end{array}$ & $\begin{array}{c}\text { Dermatitis without } \\
\text { treatment (group II) }\end{array}$ & $\begin{array}{c}\text { Dermatitis + ointment } \\
\text { "Allergolik" (group III) }\end{array}$ & $\begin{array}{c}\text { Dermatitis + ointment } \\
\text { "Fladeks" (group IV) }\end{array}$ \\
\hline Baseline & $0.90 \pm 0.05$ & $1.00 \pm 0.06$ & $0.97 \pm 0.05$ & $1.02 \pm 0.06$ \\
\hline $\begin{array}{l}\text { 10-th day of the experiment } \\
\text { (modeling of dermatitis was finished) }\end{array}$ & $0.95 \pm 0.06$ & $2.50 \pm 0.11^{*} /{ }^{* * * *}$ & $2.23 \pm 0.06^{*} / /^{* * *}$ & $2.27 \pm 0.07^{*} / * * *$ \\
\hline $\begin{array}{l}\text { 15-th day of the experiment } \\
\text { (5-th day of the skin treatment) }\end{array}$ & $0.97 \pm 0.03$ & $1.45 \pm 0.06^{*} /{ }^{* * * *}$ & $1.07 \pm 0.03^{* *}$ & $1.13 \pm 0.04^{* *}$ \\
\hline
\end{tabular}

Note: $\mathrm{n}$ - the number of animals in each group; ${ }^{*}$ - differences from group I, $\mathrm{p}<0.05$; ${ }^{* *}$ - differences from group II, $\mathrm{p}<0.05$;

*** - differences between groups III and IV, $\mathrm{p}<0.05$; ${ }^{* * * *}$ - differences from baseline data, $\mathrm{p}<0.05$. 


\section{INDEXES OF PERIPHERAL BLOOD ON THE EXPERIMENTAL MODEL OF TURPENTINE- INDUCED DERMATITIS IN RATS $\left(\bar{X} \pm S_{x}, n=6\right)$}

\begin{tabular}{|c|c|c|c|c|c|}
\hline Indexes & $\begin{array}{l}\text { Observation } \\
\text { term }\end{array}$ & $\begin{array}{l}\text { Intact animals } \\
\text { (group I) }\end{array}$ & $\begin{array}{l}\text { Dermatitis without } \\
\text { treatment (group II) }\end{array}$ & $\begin{array}{l}\text { Dermatitis + ointment } \\
\text { "Allergolik" (group III) }\end{array}$ & $\begin{array}{c}\text { Dermatitis + } \\
\text { ointment "Fladeks" } \\
\text { (group IV) }\end{array}$ \\
\hline \multirow{3}{*}{$\begin{array}{l}\text { Total leukocytes, } \\
10 \% / \mathrm{L}\end{array}$} & Baseline & $5.80 \pm 0.13$ & $5.97 \pm 0.08$ & $5.85 \pm 0.10$ & $5.95 \pm 0.11$ \\
\hline & 10-th day & $5.87 \pm 0.06$ & $18.00 \pm 0.67^{*} / * * * *$ & $18.50 \pm 0.43^{*} / * * * *$ & $18.33 \pm 0.33^{*} / * * * *$ \\
\hline & 15-th day & $5.91 \pm 0.08$ & $16.47 \pm 0.41^{*} / * * * *$ & $7.75 \pm 0.19^{*} / * * / * * * / * * * *$ & $8.60 \pm 0.1^{*} / * * / * * * *$ \\
\hline \multirow{3}{*}{$\begin{array}{l}\text { Banded } \\
\text { neutrophils, \% }\end{array}$} & Baseline & $3.50 \pm 0.43$ & $3.33 \pm 0.21$ & $3.00 \pm 0.31$ & $3.67 \pm 0.21$ \\
\hline & 10-th day & $4.00 \pm 0.26$ & $7.00 \pm 0.37^{*} / * * * *$ & $6.33 \pm 0.42^{*} / * * * *$ & $7.33 \pm 0.49 * / * * * *$ \\
\hline & 15-th day & $3.17 \pm 0.31$ & $5.50 \pm 0.34^{*} / * * * *$ & $4.50 \pm 0.22 * / * * / * * * *$ & $4.83 \pm 0.31^{*} / * * * *$ \\
\hline \multirow{3}{*}{$\begin{array}{l}\text { Segmented } \\
\text { neutrophils, \% }\end{array}$} & Baseline & $15.00 \pm 0.37$ & $15.00 \pm 0.52$ & $15.67 \pm 0.33$ & $15.33 \pm 0.42$ \\
\hline & 10-th day & $15.17 \pm 0.31$ & $26.33 \pm 0.88^{*} / * * * *$ & $21.17 \pm 0.60^{*} / * * / * * * *$ & $19.50 \pm 0.76^{*} / * * /^{* * * *}$ \\
\hline & 15-th day & $15.67 \pm 0.21$ & $20.67 \pm 0.61 * / * * * *$ & $17.50 \pm 0.96^{* *}$ & $17.83 \pm 1.19$ \\
\hline \multirow{3}{*}{ Eosinophils, \% } & Baseline & $1.00 \pm 0.37$ & $1.17 \pm 0.48$ & $1.17 \pm 0.31$ & $1.00 \pm 0.37$ \\
\hline & 10-th day & $1.17 \pm 0.40$ & $2.67 \pm 0.33^{*} / * * * *$ & $2.00 \pm 0.37$ & $2.00 \pm 0.26^{* * * *}$ \\
\hline & 15-th day & $1.33 \pm 0.49$ & $2.17 \pm 0.31$ & $1.50 \pm 0.22$ & $1.33 \pm 0.33$ \\
\hline \multirow{3}{*}{ Basophils, \% } & Baseline & $1.00 \pm 0.26$ & $0.83 \pm 0.31$ & $0.50 \pm 0.22$ & $0.83 \pm 0.31$ \\
\hline & 10-th day & $0.67 \pm 0.21$ & $1.50 \pm 0.34$ & $1.00 \pm 0.37$ & $1.33 \pm 0.21$ \\
\hline & 15-th day & $1.00 \pm 0.26$ & $1.33 \pm 0.21$ & $0.83 \pm 0.31$ & $1.17 \pm 0.17$ \\
\hline \multirow{3}{*}{ Monocytes, \% } & Baseline & $2.50 \pm 0.43$ & $3.17 \pm 0.48$ & $2.33 \pm 0.33$ & $2.17 \pm 0.54$ \\
\hline & 10-th day & $2.17 \pm 0.31$ & $4.67 \pm 0.21^{*} / * * * *$ & $3.00 \pm 0.37^{* *}$ & $2.50 \pm 0.22^{* *}$ \\
\hline & 15-th day & $3.17 \pm 0.48$ & $3.00 \pm 0.37$ & $2.67 \pm 0.33$ & $2.33 \pm 0.29$ \\
\hline \multirow{3}{*}{ Lymphocytes, \% } & Baseline & $77.00 \pm 0.63$ & $76.50 \pm 0.62$ & $77.17 \pm 0.48$ & $77.00 \pm 0.73$ \\
\hline & 10-th day & $76.83 \pm 0.60$ & $58.00 \pm 0.82 * / * * * *$ & $66.50 \pm 0.92 * /^{* *} / * * * *$ & $67.33 \pm 0.42^{*} / * * / * * * *$ \\
\hline & 15-th day & $75.67 \pm 0.88$ & $67.33 \pm 0.71^{*} / * * * *$ & $73.00 \pm 0.97^{* *} / * * * *$ & $72.50 \pm 0.99 * /^{* *} / * * * *$ \\
\hline
\end{tabular}

Note: $\mathrm{n}$ - the number of animals in each group; 10-th day - 10-th day of the experiment (modeling of dermatitis was finished); 15-th day - 15-th day of the experiment (5-th day of the skin treatment); * - differences from group I, $\mathrm{p}<0.05$; ** differences from group II, $\mathrm{p}<0.05 ; * * *$ differences between groups III and IV, $\mathrm{p}<0.05$; $^{* * * *}-$ differences from baseline data, $\mathrm{p}<0.05$.

(on the 5-th day of the skin treatment). Systemic manifestations of inflammation was decreased, which appeared in significant reduce of total leukocytes number $(2$, 1 times), banded (in 1.2 times) and segmented (in 1.1 times) neutrophils was increase the number of lymphocytes (in 1.1 times) compared with untreated animals (groups II). The changes were described above characterized the anti-inflammatory properties of investigated ointment (Tab. 3). In the group of animals were treated with reference drug "Fladeks", reliable reduction of total leukocytes number in 1.9 times were observed compared with positive control group; number of banded and segmented neutrophils was not different significantly from the untreated animals with turpentine dermatitis (Tab. 3). It should be noted that efficiency to reduce the total leukocytes number of the investigated ointment with the dry extract of licorice rhizome was reliably higher than the reference drug "Fladeks".

Based on the results of the study it can be assumed that anti-inflammatory effect of the ointment "Allergolik" probably caused by active ingredients of the dry extract of licorice rhizome. The licorice's rhizome contains saponin glycyrrhizin (up to $23 \%$ ) is a mixture of potassium and calcium salts glycyrrhizic acid. According to the literature, glycyrrhizic acid slows the release of kinins and synthesis of proinflammatory cytokines (in particular prostaglandins) [5], inhibits the release of leukotriene B4 in the inflammatory focus [11], reduces the capillary permeability [14]. The licorice's rhizome contains also 27 flavonoids with a strong anti-inflammatory activity, which is realized by inhibition of inflammatory mediators in tissues - cytokines and arachidonic acid's metabolites [1].

Thus, based on our preclinical studies on the model of turpentine-indused dermatitis in rats, it was shown that the ointment "Allergolik" with the dry extract of licorice rhizome had a pronounced anti-inflammatory effect, which is probably due to its ability to influence on reduction of capillary permeability, and olso on the cyclooxygenase and lipoxygenase pathways of arachidonic acid.

\section{CONCLUSIONS}

1. It was shown that the ointment "Allergolik" on the model of turpentine-indused dermatitis in rats had pronounced anti-inflammatory effect.

2. In the experiment, studied the effect of ointment exceeded the effect of comparison - the ointment "Fladeks".

3. The obtained results indicate a prospects the availability of ointment "Allergolik" further study for the purpose of its use in the treatment of inflammatory skin processes. 


\section{REFERENCES}

1. Азаров О. В. Флавоноиды: механизм противовоспалительного действия / О. В. Азаров, Л. П. Галактионова // Химия растит. сырья. - 2012. - № 4. C. 61-78.

2. Аммосов А. С. Солодка: химия, препараты, технология / А. С. Аммосов, В. И. Литвиненко, Т. П. Попова // Современные вопросы фармакогнозии: Межвузовск. сб. науч. трудов с междунар. участием, посвящ. 20-летию кафедры фармакогнозии. - Ярославль, 2004. - Вып. 1. - С. 26- 34.

3. Аммосов А. С. Солодка - технология, препараты, применение в мировой практике: краткий обзор патентных источников / А. С. Аммосов, В. И. Литвиненко // Фармаком. - 2003. - № 4. - С. 1-8.

4. Зупанець I. А. Клінічні лабораторні методи дослідження: [навч. посіб.] / [І. А. Зупанець, В. Ф. Москаленко, С. В. Місюрьова та ін.]. - Х.: Вид-во НФАУ; Золоті сторінки, 2001.-178 с.

5. Ипатова О. М. Фосфоглив: механизм действия и применение в клинике / О. М. Ипатова. - М.: Изд-во ГУ НИИ биомедицинской химии, 2005. - 318 с.

6. Компендиум 2007 - лекарственные препараты: в 2-х т. / Под ред. В. Н. Коваленко, А. П. Викторова. - К.: «Морион», 2007. - С. 212.

7. Реброва О. Ю. Статистический анализ медицинских данных. Применение пакета программ Statistica / О. Ю. Реброва. - М.: МедиаСфера, 2006. $312 \mathrm{c.}$

8. Рєзніков О. Г. Біоетична експертиза доклінічних та інших наукових досліджень, що виконуються на тваринах: [метод. рекоменд.] / [0. Г. Рєзніков,
А. І. Соловйов, Н. В. Добреля та ін.] // Вісник фармакол. та фармації. - 2006. - № 7. - С. 47-61.

9. Рєзніченко Н. Ю. Алергічний контактний дерматит: сучасні уявлення про лікування на основі огляду наукової літератури / Н. Ю. Рєзніченко // Актуальні питання фармацевтичної і медичної науки та практики. - 2013. - № 3. - С. 69-72.

10. Яковлєва Л. В. Вивчення ефективності нової мазі на моделі неалергічного контактного дерматиту / Л. В. Яковлєва, О. В. Ткачова // Клін. фармація. - 2010. - Т. 14, № 4. - С. 66-70.

11. Akasaka Y. Glycyrrhetinic acid prevents cutaneous scratching behavior in mice elicited by substance $P$ or PAR-2 agonist / [Y. Akasaka, T. Yoshida, M. Tsukahara et al.] // Eur. J. Pharmacol. - 2011. - Vol. 670. P. $175-179$.

12. General ethical principles of experiments in animals // Endokrinol. - 2003. - Vol. 8, № 1.- P. 142-145.

13. Olivry T. Treatment of canine atopic dermatitis: 2010 clinical practice guidelines from the International Task Force on Canine Atopic Dermatitis / [T. Olivry, D. J. DeBoer, C. Favrot et al.] // Vet. Dermatol. - 2010. № 21. - P. 233-248.

14. Patel S. S. Systematic review of plant steroids as potential anti-inflammatory agents: Current status and future perspectives / Snehal S. Patel, Jignasha K. Savjani // J. of Phytopharmacol. - 2015. - № 4 (2). P. 121-125.

15. Zapadnyuk I. P. Laboratory animals. Breeding, keeping, use in experiment / [I. P. Zapadnyuk, V. I. Zapadnyuk, E. A. Zakhariya et al.]. - Kyiv: Vyshcha Shkola, 1983. - 383 p. 
УДК 616.5-002.2:615.262:615.454.122

Л. Н. Малоштан, Есам Зургані А. Зегхдані, Л. А. Шакіна ЕФЕКТИВНІСТЬ НОВОЇ МАЗІ «АЛЕРГОЛІК» НА ЕКСПЕРИМЕНТАЛЬНІЙ МОДЕЛІ СКИПИДАРНОГО ДЕРМАТИТУ У ЩУРІВ

У зовнішньому лікуванні запальних захворювань шкіри перспективними є лікарські засоби рослинного походження. Протизапальну дію мазі «Алерголік», яка містить сухий екстракт кореня солодки, і препарату порівняння (2 \% мазь «Фладекс») вивчали на моделі скипидарного дерматиту в щурів. Ефективність мазі «Алерголік» оцінювали за загальною кількістю лейкоцитів, лейкоцитарним складом периферичної крові, товщиною шкірної складки та станом шкіри. На основі проведеного дослідження було показано, що мазь «Алерголік» чинить виражений протизапальний ефект і є більш активним препаратом порівняно з маззю «Фладекс». Ключові слова: екстракт кореня солодки; протизапальна активність; скипидарний дерматит

\section{УДК 616.5-002.2:615.262:615.454.122}

Л. Н. Малоштан, Эсам Зургани А. Зегхдани, Л. А. Шакина ЭФФЕКТИВНОСТЬ НОВОЙ МАЗИ «АЛЛЕРГОЛИК» НА ЭКСПЕРИМЕНТАЛЬНОЙ МОДЕЛИ СКИПИДАРНОГО ДЕРМАТИТА У КРЫС

Для местного лечения воспалительных заболеваний кожи перспективными являются лекарственные средства растительного происхождения. Противовоспалительное действие мази «Аллерголик», которая содержит сухой экстракт корня солодки, и препарата сравнения (2\% мазь «Фладекс») изучали на модели скипидарного дерматита у крыс. Эффективность мази «Аллерголик» оценивали по общему количеству лейкоцитов, лейкоцитарному составу периферической крови, толщине кожной складки и состоянию кожи. На основании наших исследований было показано, что мазь «Аллерголик» обладает выраженным противовоспалительным эффектом и является более активным препаратом по сравнению с мазью «Фладекс».

Ключевые слова: экстракт корня солодки; противовоспалительная активность; скипидарный дерматит

Адреса для листування:

61002, м. Харків, вул. Куликівська, 12.

Національний фармацевтичний університет
Надійшла до редакції 07.09.2016 р. 